\title{
ORGANISATIONAL MODELS IN AGRICULTURE WITH SPECIAL REFERENCE TO SMALL FARMERS
}

\author{
Nebojša Zakićl, Svetlana Vukotić2, Drago Cvijanović3
}

\section{Summary}

Agricultural value chains can be understood as the systems of people, organizations and activities needed to create process and deliver agricultural products from producers to consumers. Over time and due to huge changes that have happened in the surroundings, agricultural value chains have become very integrated and complex. Small farmers can prosper by joining in modern higher-level agricultural value chains, but there are numerous obstacles, as well. The work presents the typology of organizational models for agricultural production that consists of the models organised by producers, agribusiness companies (processors, retail chains, and intermediaries), facilitators (governments, non-governmental organisations) and completely integrated models, established by some big companies. None of these models provides ideal solutions from the perspective of small producers. However, they say that the institutions, such as cooperatives and small farmers'organisations, present important mechanisms for including small producers in modern value chains and realizing the cooperation with agribusiness companies and other important players. This is also important for decision-makers and governmental bodies that should create a suitable environment and provide support so that small farmers and their organisations can integrate in modern value chains in a successful way.

Key words: value chains, organisational models, agricultural production, small farmers

JEL: $L 23, Q 13$

\section{Introduction}

Value chains in agriculture refer to the whole range of processes and participants included in moving agricultural products from farm to fork. Dramatic changes in business environment and trends in agribusiness influence all the participants included in agricultural value chains. Over time, agricultural value chains have increasingly become integrated and complex.

1 Associate Professor, Ph.D., Union - Nikola Tesla University, Cara Dušana street 62-64, Belgrade, Serbia, Phone: +381 1132869 61, E-mail: nebojsa.z@fpb.edu.rs

2 Associate Professor, Ph.D., Union - Nikola Tesla University, Cara Dušana street 62-64, Belgrade, Serbia, Phone: +381 1134281 42, E-mail: cecavukotic@gmail.com

3 Principal Research Fellow, Associate Professor, Ph.D., Institute of Agricultural Economics, Volgina street 15, Belgrade, Serbia, Phone: +381 1169728 58,E-mail: drago_c@iep.bg.ac.rs

EP 2014 (61) 1 (225-237) 
Modern higher-level agricultural value chains seek to deliver inputs for agricultural production and processing, give rise to opportunities for semi-finished and further finished goods, contribute with higher income of the participants in these chains and serve the end users in a better way.

Agricultural producers are the starting point for the majority of agricultural value chains. Agribusiness companies (processors, wholesalers, retailers etc.) often prefer to do business with big agricultural producers for their sourcing. The challenge is to include and integrate small farmers in modern value chains as well. This requires traditional spot markets to be exchanged for coordinated trade-links between farmers, agribusiness companies and all other participants in value-chains. Besides, producers should be ready to provide agricultural products of a required quality and in a required quantity continuously.

In response to environmental challenges, different organisational models for integrating agricultural producers in value chains appeared. However, none of these models is ideal for small farmers and there is a concern that small producers can be excluded from modern value chains. These models emphasize the necessity of associating farmers. The institutions, such as cooperatives and farmers organisations and contract farming become the important mechanisms of linking producers with agribusiness companies, as well as the source of inputs, technology, information, services and credits. Cooperatives and farmers organisations can provide added value to agribusiness companies with a single contact point instead of many small fragmented farmers. From the perspective of smallholder farmers, the membership in cooperatives and farmers organisations offers numerous benefits and the possibility of inclusion in modern agricultural value chains.

Perceiving the problems inclusion of small farmers in higher-level value chains in literature, we concentrate on the following topics: value chains in agriculture, organisational models for agricultural production in value chains and the importance of cooperatives and farmers organisations. This is where the arguments we have considered come from. The methods used are those of analysis, synthesis and comparison. Selected studies are compared and summarized on the basis of the existing approaches and models.

\section{Value chains in agriculture}

The term "value chains" was initially suggested by Porter (1985) to depict how customer value accumulates along the activity chains that lead to end products or services. Porter describes the value chain as the internal processes or activities which a company performs "to design, produce, market, deliver and support its product." Shank and Govindarajan (1993) depict a value chain in broader terms looking at a company as the part of the overall valuecreating processes. According to these authors, an industry value chain starts with the valuecreating processes of a supplier who provides basic raw materials and components, continues with value-creating processes of different classes of buyers and sellers up to an end user and culminates further to the disposal and recycling of materials. According to Barnes (2004), the basic characteristic of a value chain is a market-focused collaboration; value chains allow businesses to respond to the marketplace connecting production, processing and marketing activities to market demands. 
According to Miller and da Silva (2007), value chains present a set of participants (private, public and including service providers) and activity sequences that add value in bringing a product from production to end users. In agriculture and food sectors value chains can be thought of as a set of processes and flows from the inputs to production, processing, marketing and the consumer, popularly called the process from "farm to fork". Value chains in agriculture have always been in existence in a sense that farms that were producing and the final consumer accessed the produce, with the produce itself passing through multiple channels and participants (Srinivasan, 2012). Participants in agriculture value chain can be input companies, producers (farmers), processors, wholesalers, retailers, exporters, support service providers, financial organisations and other stakeholders. Value chains can be local, national and global, connecting rural producers with traders and consumers in local environment, throughout a country, region or the world.

Over the last few decades agricultural value chains, both in developed and in developing countries, have been buffeted by many changes due to the influence of numerous factors: globalization, liberalization, regulations change, government policies, technological development, progress in agricultural production, structural changes in trade, changes in market conditions, increasing export opportunities, urban population growth, the change of consumers' needs and expectations, socio-cultural effects, etc. Agricultural value chains are becoming more integrated and complex. According to Food and Agriculture Organization (2010), traditional agricultural value chains are governed through spot market transactions that include a great number of small producers and traders. Modern value chains are featured by vertical coordination, consolidation of the supply base, higher profits for the chain participants, agro-industrial processing and using standards along the chain. In literature, they are defined as developed, organised or higher-level value chains (Sjuaw-Koem-Fa, 2012; International Finance Corporation, 2012; Nagarajan et al., 2008). Anyhow, both traditional and modern systems include small farmers.

According to Miller and Jones (2010), there are generally five types of connections between buyers and sellers in agricultural value chains: 1) the instant or spot market, where producers sell their commodities themselves, wherein the prices fluctuate; 2) contract farming, i.e. agreement between producers and agribusiness organisation, government body or individual entrepreneur; 3 ) long-term and often informal relations (relation-based partnership) between the participants that are defined by trust and interdependence; 4) capital investments in production by a buyer that are defined by a high level of producer's credibility and dependency (capital investment-based partnership) and 5) vertically integrated company. The first type is typical of a traditional value chain and undeveloped markets and it is the most risky when it comes to setting market prices. In more developed higher-level value chains, contractual and partner structures where participants can respond to market needs in a more adequate ways and market principles can be better controlled are preferred.

Different activities of division of labour among the companies in a value chain are the subjects of governance. According to Gereffi et al. (2001), some companies in value chains directly or indirectly influence production, the organisation of production, EP 2014 (61) 1 (225-237) 
logistics and marketing systems. Governance includes: coordination within a value chain (inter-firm networks, quasi-hierarchical relations between lead firms and subordinated companies and a vertical integration within a company), power resources, governance structures and the ability of one firm to influence the activities of other firms in the chain. Trinekens (2011) emphasizes different governance forms in modern value chains: longterm contracts, joint ventures and vertical integration. Standardization is often used as a mechanism of coordination; also, coordination is facilitated by modern information and communication technologies.

\section{Organisational models for agricultural production in value chains}

Agricultural value chains allow businesses to respond to the marketplace by linking agricultural production, processing and marketing activities to market demands. The participants in agriculture value chains are increasingly becoming interdependent; market conditions and consumers' needs require from all participants in a value chain to work together and harmonize their activities. Although, all the participants in a value chain have a common interest, it is not easy to establish and maintain smooth working relations between them (Mangnus, Piters, 2010). This especially refers to adequate involvement of small farmers into a value chain. It is not easy to organise and stabilize agricultural value chains, especially in situation where there are a lot of small producers. The production and aggregation parts of value chains should be efficient for smallholder farmers so that they can have adequate returns (Srinivasan, 2012). According to Sjauw-Koem-Fa (2012) a real challenge is how small farmers can be connected in a market and integrated into the farm-to-fork value chains.

In majority of countries, smallholder farmers are dominant producers in agriculture, including Serbia. According to the census of agriculture in Serbia in 2102 (Statistical Office of the Republic of Serbia, 2013) Serbia has 631.552 agricultural holdings, out of which 628.552 family holdings and 3.000 legal entities and unincorporated enterprises. Family holdings have the share of $99.8 \%$ in land $(1-10$ ha), $99.2 \%$ from $10-50$ ha, i.e. $89.1 \%$ above 50ha.

Different buyers and sellers in value chains, including smallholder farmers, operate in a specific market context. Despite the development of value chains, there are still some agricultural producers that continue to market their goods through traditional informal channels and street markets. Although the possibilities for small farmers are increasing with value chains development, there are numerous barriers. According to Mangnus and Piters (2010), smallholder farmers do not have an easy access to important factors that are needed to deliver products in compliance with market needs. Smallholder farmers are faced with strong economic and other limitations. They are limited by difficult access to capital and bank loans, support services and agricultural inputs, they lack adequate technology and equipment, they have difficulties in delivering products of required quality and quantity. A special problem is the lack of adequate market information, knowledge and consulting. From the other hand, serious players in value chains (processors, wholesalers, retailers, exporters) request reliable producers - business partners that can respond to market requirements and deliver products at a reasonable price, in required quantity, delivery time and with required quality, consistently 
over a long period of time. They can find that smallholder farmers cannot respond to their requirements, striving to make contracts with bigger producers that can deliver large volumes and food quality standards (Birthal, Joshi, 2007). In a market game the winners are those who can be better, i.e. those that can offer the products of better quality, in needed quantity, a lower price, fulfil quality standards of products and processes, possess sophisticated equipment, etc. (Paraušić et al., 2007).

As food production has become increasingly industrialized and globalized, both vertical and horizontal linkages are coordinated in a stronger way and organisational arrangements that appear are more complex (Cook et al., 2008). According to Vorley et al. (2009), agricultural production organisation becomes essential in overcoming costs, associated with a dispersion of agricultural producers, diseconomies of scales, by more difficult access to information, finances, technology, inconsistency in quantity and quality and issues in connection with traceability and risk management. The challenge for researchers is to categorize a great number of different situations and organisational arrangements that appear in practice. If the typology is considerably divided, we can lose sight of the coherence of similar organisational forms. Also, it should be comprehensive enough to refer to all relevant cases.

According to Vorley et al. (2009), different organisational models of agricultural production in a value chain can be divided into three categories:

1) Producer-driven. In this model drivers of organisation are small farmers themselves, farmer's organisations and cooperatives, as well as large scale farmers. Their focus is on selling. This includes identifying attractive markets, achieving higher market prices and stabilizing market position. The aims of large-scale farmers include extra supply volumes.

2) Buyer-driven. Here, the drivers of organisation are processors, retailers and exporters. These models require efficiency in a chain for the benefit of processing and retail. The main aim is to assure supply. The most used buyer-driven value chain model is contract farming.

3) Intermediary-driven. This model functions with chain intermediaries, with intention to be profitable in highly competitive, price-sensitive markets. Drivers in this model are traders, wholesalers and other market actors and the main goal is to supply more discerning customers. Beside commercial players in these model, governmental agencies as well as non-governmental organisations with strategic focus on regional development, i.e. focus on "make markets work for the poor" can act as drivers.

Sjauw-Koem-Fa (2012) modifies this categorisation suggesting four basic organisational models:

1) Producer-driven. Meaning the same as producer-driven in the previous one.

2) Buyer-driven. In contrast to the previous category, in buyer-driven model commercial chain intermediaries (traders, wholesalers etc.) are added as the actors. The strategic focus in this model is on buying-sourcing, i.e. ensuring the procurement of sufficient supplies in set deadlines and with the required quality. The rationale for this model is to assure supply, enhancing supply volumes, as well as to supply more discerning customers (meeting market niches and different needs).

EP 2014 (61) 1 (225-237) 
3) Facilitator-driven. In this model, governmental agencies and non-governmental organisations are clearly distinguished as the drivers of organisation. This is expressed in situations with dual agricultural systems where, beside agribusiness players, there are smallholders to whom agriculture means rather a survival with a little surplus for sale or trade, then commercial production.

4) Integrated. This model is a special type of vertical integration that integrates numerous stakeholders into a value chain through the ownership and/or contractual relations. The drivers of organisation are lead firms, supermarkets or multinational companies. Their goals refer to new and higher market values, low prices for good quality or market monopoly.

These models are given in table 1.

Table 1. Organisational models for agriculture production in value chains

\begin{tabular}{|c|l|c|}
\hline Sjauw-Koem-Fa (2012) & \multicolumn{1}{|c|}{ Driver of organisation } & Vorley et al. (2009) \\
\hline \multirow{3}{*}{ Producer-driven } & $\begin{array}{l}\text { Smallholder farmers themselves, } \\
\text { cooperatives, farmers organisations }\end{array}$ & \multirow{2}{*}{ Producer-driven } \\
\cline { 2 - 2 } & Large-scale farmers & \multirow{2}{*}{ Buyer-driven } \\
\hline \multirow{3}{*}{ Buyer-driven } & Processors & \\
\cline { 2 - 2 } & Exporters & \multirow{2}{*}{ Intermediary-driven } \\
\cline { 2 - 2 } & Retailers & \\
\cline { 2 - 2 } & Traders (local), wholesalers & \\
\hline \multirow{2}{*}{ Facilitator-driven } & NGOs and other support agencies & \\
\cline { 2 - 2 } & National and local governments & \\
\hline \multirow{2}{*}{ Integrated } & Lead firms & \\
\cline { 2 - 2 } & Supermarket chains & \\
\cline { 2 - 3 } & Multinational companies & \\
\hline
\end{tabular}

Source: Adapted from Vorley et al. (2009) and Sjauw-Koem-Fa (2012)

\section{Small farmers and the importance of cooperatives and farming organisations}

We are here mostly interested in small farmers. According to Vorley et al. (2009), despite numerous benefits, none of these models is superior for small farmers. For the participation of small farmers in dynamic and more profitable market segments their skill level, which includes capacities focused on market linkages, the increase of social capital and development of management abilities, should increase (Camacho et al., 2007).

For development of these skills, the key factors are: effective support services (managerial and others), effective enabling environment and making efficient alliances with chain actors (Vorley et al., 2009). According to Birthal and Joshi (2007), for smallholder farmers to benefit from increasing market possibilities, close linkages between farmers and different stakeholders in value chains are necessary to coordinate supply and demand. Institutions like cooperatives, farmer's organisations and contract farming can help creation of such links. 
In producer-driven value chain models, agricultural cooperatives and other farmer-based organisations strive to establish direct links with end markets and they seem as development drivers of a value chain. A cooperative is defined as a business operated primarily to provide benefits to members through marketing transactions and through the distribution of earnings from these transactions (Coltrain et al., 2000). Farmer's organisations are more flexible forms of associating farmers than cooperatives. They can be considerably different, more or less formal, but also have certain benefits for their members (Dorward, Kachule, 2005). In defining cooperatives and farmers organisations, three basic principles developed from Dunn (1988) are used:

1. The User-Owner Principle. This principle tells us that those who own and finance the cooperative are the ones who use the cooperative.

2. The User-Control Principle. According to this principle, those who control the cooperative are the ones who use the cooperative.

3. The User-Benefits Principle. The third principle says that the aim of a cooperative is to provide and distribute benefits to its users on the basis of their use.

According to Conell (1999), cooperatives may be the clearest example of collective entrepreneurship. They are, by definition, a collective effort. Cooperatives correspond to the logic of collective action. First, cooperatives are privileged groups: it is expected that the net benefit to at least one individual is positive. Second, convention may also play a role in keeping cooperatives functioning. According to Vorley et al. (2009), collective action is an important strategy to increase small farmer participation in emerging modern markets and to create sustained commercial flows of high-quality products.

In buyer-driven models, the drivers (processors, retailers, exporters, etc.) strive to avoid the addiction of traditional wholesale markets in the pursuit of value and product assurance, although one of the reasons for such models development is the lack of collective action of producers (Sjuaw-Koem-Fa). The most frequent option of the buyer-driven model, contract farming, is in expansion in the world (International Institute for the Unification of Private Law, 2013) as a way to organise and connect production capacities and market needs, to enhance the product range and to diversify it in local, regional and global markets, as well as to improve a value chain efficiency.

According to Food and Agriculture Organization (2001), contract farming has numerous benefits for small farmers: inputs and production services are often supplied by the investor, this is usually done on credit through advances from the investor, the price risk is reduced since many contracts specify the price in advance and contract farming opens new markets that would otherwise be unavailable to small farmers. It also provides new technologies introduction and mastering new skills. However, contract farming can be also seen as partnerships of uneven partners where there is always some space for exploitation of the weaker party - small farmers. Also, investors can have risks and difficulties in getting smallholders to comply with standard requirements and to fulfil commitments (Elbehri, 2013).

EP 2014 (61) $1(225-237)$ 
Organisational models analysis for agricultural production in value chains emphasizes the role of cooperatives and farmers organisations. Cooperative organising proved itself to be a sustainable, accepted and the successful type of agricultural production development, the way of entering and survival in a market, the penetration of capital in small farmers activities, as well as differentiation and individual enhancement of some of them (Maričić, 2009). The primary goal of all cooperatives is the benefit of their members, so that they can improve their economic, social and cultural position. Agricultural cooperatives offer benefits of collective power, help the increase of income of their members and enhance negotiating power. According to other participants in a value chain, they provide important services, a wider market for their products, as well as by achieving better prices for farmers, help them acquire better entrepreneurial and marketing skills, etc. Beside the benefits for their members - farmers, cooperatives provide other benefits to local (rural) community and consumers (Rodriguez, 2011; Food and Agriculture Organization, 2012). Also, farmer's organisations do not exclusively cover directly measurable economic returns, but also a social capital and community development (Dorward, Kachule, 2005).

Cooperatives and contract farming are not are not mutually exclusive. Negotiating power of cooperatives is bigger than the power of individuals (unless if the question is about big farms of a single owner). Agribusiness companies may prefer cooperatives since group liabilities for credits provide the reduction of lending risks while the economy of scale can make transactional costs smaller (Coutler et al., 1999).

According to Bijman et al. (2012), the position of cooperation in a value chain refers to the competitiveness of cooperatives in relation to other participants, such as processors, wholesalers and retailers, as well as the strategy which a cooperative formulates when choosing its position in a value chain. Beside the position in a value chain, the performance of a cooperative is influenced by internal governance and institutional environment. Internal governance refers to decision-making processes adopted, the role of the different governing bodies, the deployment of control rights to members and professional management, and issues such as the organisational structure of the cooperative enterprise, including the formation of holdings and subsidiaries. Institutional environment refers to social, cultural, political and legal contexts in which a cooperative functions and that can have both positive and negative effects on motivation for starting up and joining cooperatives as well as on cooperatives' performance.

According to Chaddad (2006), cooperatives can be organised in a multi-layered fashion which is designated as a federated structure. In such structures, patrons are the members of a local cooperative that is a member of a regional cooperative. Regional cooperatives can also join and form national or interregional cooperatives. Also, there are international cooperatives. In this way, federal structure enhances the power of local cooperatives considerably as well as the position in value chains. 
Cooperatives and farmers organisations are one of the essential mechanisms for including small farmers in organised value chains. They are formed with the motivation of common benefits and expectation of collective action among the members (Hong, Sporleder, 2007). Farmers should recognize that they solve their problems or take advantage of an opportunity together, instead of trying to do this individually. However, this does not mean that cooperatives and farmers organisations will be a certain success, although they offer benefits of collective powers. Many cooperatives and farmers organisations with economic and market targets have bad results due to some internal factors: internal governance, leadership, members, management, training and education, technology etc. as well as some external factors: weak/ difficult links in a value chain with input suppliers, agribusiness partners, finance/credit institutions, credit burden and debtors, the lack of support from public institutions, etc. (Garnevska et al., 2011; Elbehri, 2013).

Legal environment and governmental policy are one of the key factors of success (Garnevska et al., 2011). According to Cvijanović et al. the institutional barriers (inefficient legislation and justice system) limit small farmers in developing forms of association that give the best results. In the research of cooperatives that was carried out by Zakić et al. (2013) in Serbia, the perception of the members of cooperatives is such, that in a high percent they think that the cooperatives in Serbia are neglected and that the state does not support their development. Although, according to Laidlaw (1980), a state should never dominate, direct and try to manage cooperatives. It has to encourage, support and sometimes provide cooperatives with financial help. The state should have a supporting role, encouraging inclusion of smallholders. Governments, according to Birthal and Joshi (2007), should facilitate the up scaling of cooperatives and farmers organisations by demonstrating the benefits of these institutions to small farmers and their inclusion in modern higher level value chains.

\section{Conclusion}

The full usage of agricultural potential is possible if small producers are linked to markets in a way that they can realise bigger income and other benefits. The value chain approach offers good possibilities for small farmers to be included in modern higher-level value chains instead of traditional spot-markets. However, small farmers are faced with numerous obstacles in accessing all the factors that are needed for the delivery of agricultural products that comply with market requirements. Although, small farmers and companies included in agribusiness (and a society in general), can prosper by integrating small farmers in modern value chains, the challenges of realising collaboration of agribusiness with small farmers is overcoming different obstacles faced by small farmers (from obtaining raw materials to the access to finances and technology improvement), the reliability of partnerships with small farmers so that they could respond to different market needs, provide the achievement of the required quality standards and deliver agricultural products in required quantity, within the set time limits and continuity.

In response to environmental challenges, different organisational models for agricultural production have evolved. These models can be organised by the very producers, companies that are end customers or intermediaries (traders, wholesalers, exporters), organisations

EP 2014 (61) 1 (225-237) 
that assist the integration of smallholders into value chains (government agencies, nongovernmental organisations) or the question is about completely integrated models in which the driver is a big company (for example a supermarket chain). Although, none of these models is completely suitable for small farmers, the models emphasize that the possibilities for cooperation between small farmers and agribusiness companies and the inclusion of small farmers in modern value chains grow if small farmers come together in cooperatives and producer organisations. These institutions provide the inclusion of small farmers in organised value chains and the realisation of numerous benefits for their members and local community, while at the same time, enable agribusiness companies to meet their requests. The creation and successful operation of these organisations depend on many internal and external factors, including governmental policy as a very important factor of success. Policy decision makers are of central importance in the policy environment creation and providing support in order to make the integration of small farmers into modern agricultural value chains easier.

\section{References}

1. Barnes, M. (2004): Value chain guidebook: A process for value chain development, Nisku, Alberta, Agriculture and Food Council of Alberta, Value Chain Initiative.

2. Bijman, J., Iliopoulos, C., Poppe, J. K., Gijselinckx, C., Hagedorn, K., Hanisch, M., Hendrikse, G. W. J., Kühl, R., Ollila, P., Pyykkönen, P., van der Sangen, G. (2012): Support for Farmers' Cooperatives, European Commission, Brussels.

3. Birthal, P. S., Joshi, P. K. (2007): Smallholder Farmers'Access to Markets for High Value Agricultural Commodities in India, Cornel University, New York.

4. Camacho, P., Marlin, C., Zambrano, C. (2007): Elementos orientadores para la gestion de empresas asociativas rurales, Platforma RURALTER, Mesa de trabajo en Desarrollo Economico, Quito.

5. Chaddad, F. R. (2006): Networking for competitive advantage, $17^{\text {th }}$ annual world symposium of the International Food and Agribusiness Management Organization, June, Parma.

6. Cook, M. L., Klein, P. G., Iliopoulos, C. (2008): Contracting and Organization in Food and Agriculture, In: Brousseau, E., Glachant, M. J. (edt.), New Institutional Economics, Cambridge University Press, New York.

7. Coltrain, D., Barton, D., Boland, M. (2000): Differences Between New Generation Cooperatives and Traditional Cooperatives, Arthur Capper Cooperative Center, Kansas State University.

8. Conell, D. J. (1999): Collective Entrepreneurship: In Search of Meaning, University of Northern British Columbia, Prince George.

9. Coutler, J., Goodland, A., Tallontire, A., Stringfellow, R. (1999): Marring Farmer Cooperation and Contract Farming for Agricultural Service Provision, Guide to Developing Agricultural Markets and Agroenterprises Series, World Bank, Washington D.C. 
10. Cvijanović, D., Pejanović, R., Paraušić, V. The analysis of different cooperative forms in primary agriculture in the function of overcoming basic barriers of competitiveness of the agriculture of Serbia (in Serbian). The paper is being prepared for publication.

11. Dorward, A., Kachule, R. (2005): Farmers organisations for market access in Malawi, Proceedings of a stakeholders workshop on farmer organisations for market access in Malawi, February, Lilongwe.

12.Dunn, J. R. (1988): Basic cooperative Principles and their Relationship to Selected Practices, Journal of Agricultural Corporation, no. 3, pp. 83-93.

13. Elbehri, A. (2013): Rebuilding West Africa's food potential, In: Elbehri, A. (edt.). Policies and market incentives for smallholder-inclusive food value chains, Food and Agriculture Organization and International Fund for Agricultural Development, Rome.

14. Food and Agricultural Organization (2012): Agricultural cooperatives: paving the way for food security and rural development, Rome.

15. Food and Agriculture Organization (2010): Agricultural Value Chain Development, Rome.

16. Food and Agriculture Organization (2001): Contract Farming: Partnerships for Growth, Rome.

17. Garnewska, E., Guozhong, L., Shandbolt, N. (2011): Factors for Successful Development of Farmers Cooperatives in North West China, International Food and Agribusiness Management Review, vol. 14(4), pp. 69-84.

18. Gereffi, G., Humphrey, J., Kaplinsky, R., Sturgeon, T. J. (2001): Globalisation, Value Chains and Development, In: Gereffi, G., Kaplinsky, R. (edt.): The value of value chains: Spreading the gains from globalization, Institute of Development Studies, Brighton.

19. Hong, G., Sporleder, T. L. (2007): Social capital in agricultural cooperatives: Application and measurement, The Ohio State University, Columbus.

20. International Finance Corporation (2012): Innovative Agricultural SME Finance Models, Washington DC.

21. International Institute for the Unification of Private Law (2013): Formulating International Legal Guidance on Contract Farming, Rome.

22. Laidlaw, A. F. (1980): Cooperatives in the year 2000, $27^{\text {th }}$ Congress of the International Cooperative Alliance, October, Moscow.

23. Maričić, B. (2009): Cooperatives - alternatives to deterioration of farms and villages (in Serbian), Economics of Agriculture, vol. 56(1), pp. 157-163.

24. Mangnus, E., Piters, B. S. (2010): Dealing with small scale producers: linking buyers and producers, KIT Publishing, Amsterdam.

25. Miller, C., Jones, L. (2010): Agricultural value chain finance, Food and Agricultural Organization, Rome and Practical Acton Publishing, Rugby.

26. Miller, C., da Silva, C. (2007): Value chain financing in agriculture. Enterprise Development and Microfinance, vol. 18(2-3), June/September 2007, pp. 95-108. 
27. Nagarajan, G., Leegwater, A., Shaw, A. (2008): Forward linkages and well-being of outsource microenterprise households in Peru, US Agency for International Development, Washington, DC.

28. Porter, M. (1985): The Competitive advantage of Nations, New York, Free Press.

29. Paraušić, V., Cvijanović, D., Subić, J. (2007): Affirmation of cooperation and marketing in the function of creation of the agricultural sector of Serbia (in Serbian), Institute of Agricultural Economics, Beograd.

30. Rodriguez, J. D. G. (2011): Smallholders'agricultural cooperatives and rural development in Colombia, University of Oxford, St. Antony's College, Oxford.

31. Shank, J. K., Govindarajan, V. (1993): Strategic cost management, New York, Free Press.

32. Sjauw-Koem-Fa (2012): Cooperatives - a Key for Smallholder Inclusion into Value Chain, Rabobank Group, Uthrecht.

33. Srinivasan, N. (2012): Indian experience of application of agricultural value chain finance, Workshop on Enhancing Exports' Competitiveness, South Africa, November.

34. Statistical Office of the Republic of Serbia (2013): Census of Agriculture 2012 in the Republic of Serbia - Agriculture in the Republic of Serbia, Beograd.

35. Trienekens, J. H. (2011): Agricultural Value Chains in Developing Countries: A Framework for Analysis, International Food and Agribusiness Management Review, vol. 14(2), pp. 51-82.

36. Vorley, B., Lundy, M., MacGregor, J. (2009): Business models that are inclusive of small farmers, In: Silva, C. A., Baker, D., Shepherd, A. W., Jenane, Ch., Miranda-daKruz, Agro-industries for development, Food and Agriculture Organization, Rome, UN Industrial Development Organization, Vienna.

37.Zakić, N., Vukotić, S., Laketa, M., Laketa, L. (2013): Agricultural Co-operatives: Researching Members Perception of Important Issues of Co-operatives on the Examples of Serbia, The Journal of Animal and Plant Sciences, vol. 23(1), pp. 290-297. 


\title{
ORGANIZACIONI MODELI U POLJOPRIVREDI SA POSEBNIM OSVRTOM NA MALE POLJOPRIVREDNIKE
}

\author{
Nebojša Zakič́, Svetlana Vukotićs ${ }^{5}$ Drago Cvijanović ${ }^{6}$
}

\section{Rezime}

Lanci vrednosti u poljoprivredi mogu biti shvaćeni kao sistemi ljudi, organizacija $i$ aktivnosti potrebni da se kreiraju, obrade $i$ isporuče poljoprivredni proizvodi od proizvođača to potrošača. Tokom vremena, usled velikih promena koje su se dešavale u okruženju, poljoprivredni lanci vrednosti su postali vrlo integrisani i kompleksni. Mali poljoprivrednici mogu prosperirati od uključenja u savremene poljoprivredne lance vrednosti višeg nivoa ali postoje brojne prepreke. U radu se daje tipologija organizacionih modela za poljoprivredenu proizvodnju koju čine modeli organizovani od strane proizvođača, kompanija u agrobiznisu (prerađivači, maloprodajni lanci, posrednici), facilitatora (vlada, nevladine organizacije) i potpuno integrisani modeli uspostavljeni od strane neke velike kompanije. Nijedan od ovih modela ne daje idealna rešenja sa stanovišta malih proizvođača. Međutim oni govore da institucije kao što su zadruge i organizacije malih poljoprivrednika su važni mehanizmi za uključenje malih proizvođača u savremene lance vrednosti i ostvarenje saradnje sa kompanijama $u$ agro biznisu i drugim važnim igračima. Ovo je važno i za donosioce odluka $i$ vladine organe koji treba da kreiraju odgovarajuće okruženje i pruže podršku kako bi se mali poljoprivrednici i njihove organizacije uspešno integrisali u savremene lance vrednosti.

Ključne reči: lanci vrednosti, organizacioni modeli, poljoprivredna proizvodnja, mali poljoprivrednici

4 Vanredni profesor, Univerzitet - Union Nikola Tesla, Beograd, Cara Dušana 62-64, Beograd, Telefon: +381 1132869 61, E-mail: nebojsa.z@fpb.edu.rs

5 Vanredni profesor, Univerzitet - Union Nikola Tesla, Beograd, Cara Dušana 62-64, Beograd, Telefon: +381 1134281 42, E-mail: cecavukotic@gmail.com

6 Naučni savetnik, vanredni profesor, Institut za ekonomiku poljoprivrede, Beograd, Volgina 15, Beograd, Telefon: +381 1169728 58, E-mail: drago_c@iep.bg.ac.rs

EP 2014 (61) 1 (225-237) 